\title{
$\pi$ OR $\Pi ?$
}

\author{
A NOTE ON THE CHRONOLOGY \\ OF EUSEBIUS'S MARTYRS OF PALESTINE
}

\begin{abstract}
Summary: Accepting the dates in the short version of Eusebius of Caesarea's De martyribus Palestinae as correct and assuming that in defining the holidays and the days of the week the author followed the Christian calendar of Caesarea - which was not identical with the Roman one - it seems likely that the martyr Apphianus was executed not on a simple Friday (MP rec. brev. 4, 15: $\dot{\eta} \mu \varepsilon \rho \alpha \pi \alpha \rho \alpha \sigma \kappa \varepsilon v \tilde{\eta} s$ ), but on Good Friday (
\end{abstract}

Key words: Eusebius, De martyribus Palestine, Christian calendar, Caesarea, martyr Apphianus, Good Friday.

The Martyrs of Palestine (MP), written by Eusebius of Caesarea, is known in two versions. The short version (MP rec. brev.) survived in a group of manuscripts (ATER) of his Ecclesiastical History (HE), the long one in a Syriac translation (MP rec. long.) and in Greek fragments. ${ }^{1}$

The dates in connection with the great persecution (303-313) seem to be somewhat problematic in Eusebius' work. After establishing the date of the beginning of the persecution, the chronological frame of the MP is set by internal references, i.e. the second, third, fourth (etc.) year of the persecution. As well as the reckoning based on it - "the years of the war against the Christians" - Eusebius often uses the months and days of the Macedonian and Roman year, too.

Lawlor attempted to give more exact dates concerning the chronological frame of the MP and to throw new light upon Eusebius' work and the persecution. ${ }^{2}$ First he dates the martyrdom of Apphianus, executed in the fourth year of the persecution, to 306. Then he goes on to argue that the years of the internal chronology of the MP are practically identical with the years of our reckoning. ${ }^{3}$

In four cases the MP rec. brev. determines the days of the executions not only by giving the year of the persecution and the month and day according to the Mace-

\footnotetext{
${ }^{1}$ The edition of the MP rec. brev. and the Greek fragments of the MP rec. long.: SCHWARTZ, E.: Eusebius Werke II. 2. (GCS). Leipzig 1908, 905-950.

${ }^{2}$ LAWLOR, H. J.: The Chronology of Eusebius's Martyrs of Palestine. Eusebiana. Oxford 1912 (repr. Amsterdam 1973) 179-210. $96-100$.

Against this, see RiCHARDson, G. W.: The Chronology of Eusebius: Addendum. CQ 19, 1925,
} 
donian and Roman calendar, but also by recording which day of the week that certain day was. After taking a closer look at these four dates, Lawlor concludes that "every one of these four dates is incorrect. And not only is each by itself proved to be erroneous, but they are also inconsistent with one another."4

Lawlor's supposition seems to be highly improbable - if not incredible - for four obvious reasons:

(1) two of the four dates are also confirmed by the MP rec. long.;

(2) all four martyrs had been executed in Caesarea, and thus Eusebius had most likely been an eye-witness of their martyrdom; as well;

(3) Eusebius was not only the "father of church history", but a chronographer

(4) the MP rec. brev. was probably finished shortly after the so-called palinodia of Galerius and before the revival of the persecution under Maximinus, i.e. between May and November 311, and is sure to have been published and circulated, presumably as an appendix to the $\mathrm{HE}$ counting eight volumes at the time; ${ }^{5}$ the contemporary reader could remember the events and dates fairly well and would have detected any errors of this nature.

Let us examine the four dates in question.

1 .

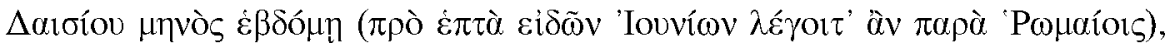

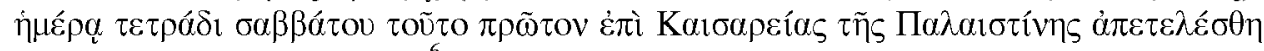

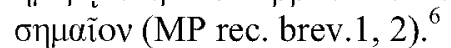

2.

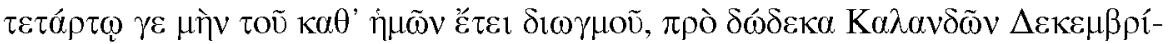

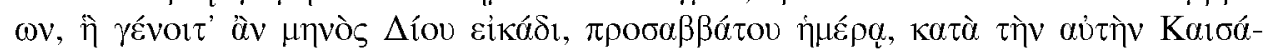

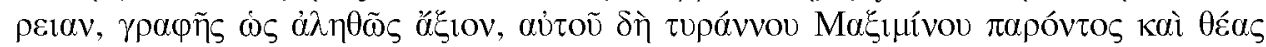

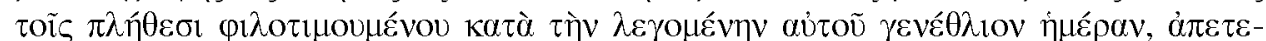

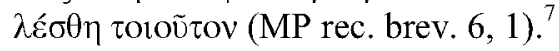

\footnotetext{
${ }^{4}$ LAWLOR, op. cit. (note 2), 193.
${ }^{5}$ Cf. SCHWARTZ, E.: Eusebius Werke II. 3 (GCS). Leipzig 1909, XLVII-LXI; LAWLOR, H. J.: Eusebiana. Oxford 1912 (= repr. Amsterdam 1973), 243-291. See also BARNES, T. D.: The Editions of Eusebius' Ecclesiastical History. GRBS 21, 1980, 191-201; LOUTH, A.: The Date of Eusebius's Historia Ecclesiastica. JThS n.s. 41, 1990, 111-123.

${ }^{6}$ SCHWARTZ, op cit. (note 5), in app. ad locum: der 7. Juni 303 war ein Dienstag. LAWLOR, op. cit. (note 2), 192: In 303 the 7th of June was not a Wednesday, but a Monday.

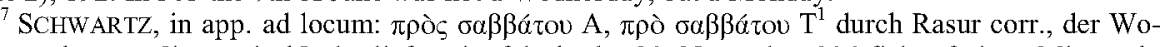
chentag, auch von s [i.e. syrisch] überliefert, ist falsch, der 20 . November 306 fiel auf einen Mittwoch. LAWLOR, op. cit. (note 2), 191: Since there is no reasonable ground for doubting that November 20 was

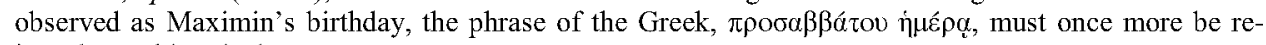
jected as unhistorical.
} 
3.

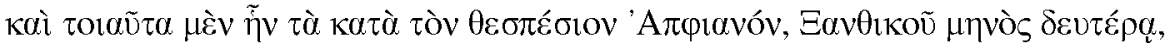

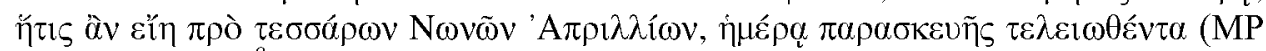
rec. brev. 4,15$)^{8}$

4. 1 .

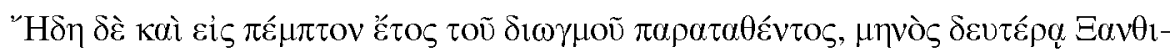

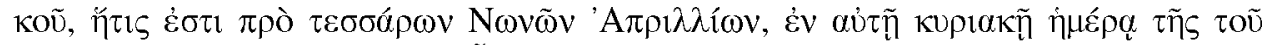

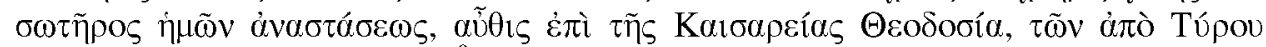
$\pi \alpha \rho \theta \varepsilon \hat{v o s}$ (MP rec. brev. 7, 1). ${ }^{9}$

4. 2.1.

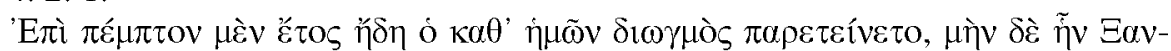

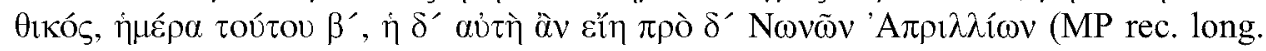
$7,1)$.

4. 2. 2 .

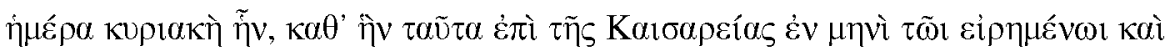

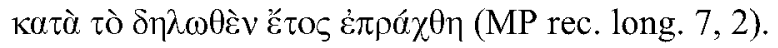

Lawlor came to his erroneous conclusion because when he tried to assign the four dates to specific days of the week, he worked with a reckoning different from the one used by Eusebius. (The same mistake was also made by others, for example by Schwartz.) In the four cases when Eusebius specifies the days of the week as well, he obviously does so according to the Caesarean Christian year and not to the Julian or Gregorian (perpetual) calendar. It is also worth remembering that beside the Christians, Samaritans and pagans in Caesarea, the town also had a sizeable Jewish community, ${ }^{10}$ and thus the days of the week in the Jewish calendar might also have had some influence on the Christian calendar of the city.

Assuming that the days of the week were specified correctly by Eusebius in the case of all four dates, Rey-Coquais reconstructed the Antiochian calendar, which he believed to be identical with the Caesarean one, from the very four dates in ques-

${ }^{8}$ SCHWARTZ, in app. ad locum: der 2. April war ein Dienstag. LAwLoR, op. cit. (note 2), 190 sq.: We must (...) make our choice between rejecting the day of the week in the Greek text, and rejecting the day of the month in both Greek and Syriac. Here the Syriac comes to our aid. In it we read, 'Such was the termination of the history of Epiphanius [i.e. Apphianus], on the second of the month Nisan, and his memory is observed on this day.' [Transl. by Cureton] Thus contemporary tradition confirms the date April 2. This is decisive in favour of the supposition that the words $\dot{\eta} \mu \varepsilon \rho \alpha \_\alpha \rho \alpha \sigma \kappa \varepsilon v \tilde{\eta} \varsigma$ are an incorrect gloss, whether of Eusebius or someone else.

${ }^{9}$ SCHWARTZ, in app. ad locum: Ostersonntag $307=6$. Xanthikos. LAWLOR, op. cit. (note 2 ), 193: both Greek and Syriac give April 2 in the fifth year as the day of the martyrdom of Theodosia. The Syriac declares that it was Sunday; and the Greek addition may have the same meaning - غ่v aú $\tau \tilde{\eta}$

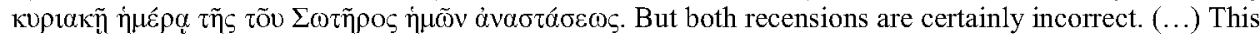
example is interesting, because the agreement of the Syriac and the Greek makes it highly probable that the error originated with Eusebius himself.

${ }^{10}$ Levine, L. I., The Jewish Community at Caesarea in Late Antiquity. Caesarea Papers. Straton's Tower, Herod's Harbour, and Roman and Byzantine Caesarea. Ed by R. L Vann. Ann Arbor, MI 1992, 268-273; LIFSCHITZ, B.: Césarée de Palestine, son histoire et ses institutions. ANRW II. 8. BerlinNew York 1977, 490-518. 
tion. ${ }^{11}$ However, his attempt must be considered hypothetical until new evidence is found to support Rey-Coquais' theory.

The order of the movable feasts in the Christian calendar is determined by the date of Easter. The setting of this date was preceded by serious debates even before Eusebius' time (HE 4, 14, 1; 4, 26, 3-4; 5, 23-25), and Rome's view (HE 5, 23, 2) was ignored in many areas in the East. In the HE Eusebius often refers to the different views of the Christian authors (HE 6, 22; 7, 32, 13-19), and he also notes that Caesarea celebrates Easter with Alexandria (HE 5, 25), which in this context definitely means that not on the days set by Rome. ${ }^{12}$

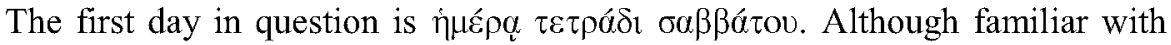

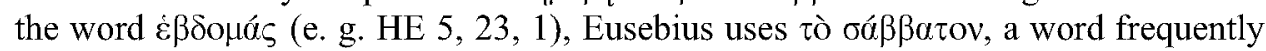
used in the New Testament, for the week. The basic day of the week was Saturday

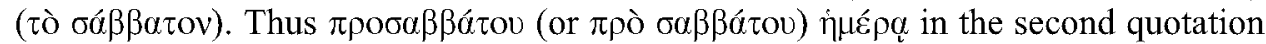
means: on Friday. According to Lawlor (and others) the expression $\dot{\eta} \mu \varepsilon \dot{\varepsilon} \rho \alpha \alpha \rho \alpha-$

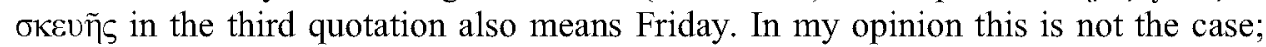

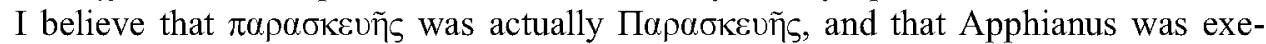
cuted not on a simple Friday, but on Good Friday.

The following arguments support my hypothesis:

(1) When setting the chronological frame of the MP Eusebius seems to have been using five different kinds of reckoning. At the beginning he states that the persecution was the result of the decrees passed in the 19th year of Diocletian's reign, when Flavian was the governor of Palestine. ${ }^{13}$ Beside giving the year of the emperor's rule and the governor's name, he gave the months and days according to the Macedonian and the Roman calendar as well. The fifth way is his reference to the Christian calendar, apparent in the cases when he mentions the days of the week. The four dates in question point towards the relevance of the Christian calendar, naturally a Caesarean one, identical with the Alexandrian (or Antiochian) one, and definitely not with the Georgian one. If someone should want to synchronize the Christian year with other chronological systems, they would have to set the date of Easter as the most important piece of information - just as Eusebius seems to have done.

(2) When compared the HE 8, 2, 4 and the MP prooem. show a striking similarity, which makes it hard to understand why the month when the persecution began

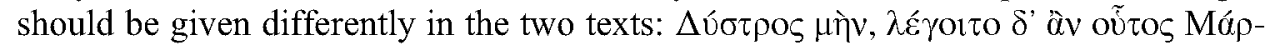

${ }^{11}$ REY-COQuAIS, J.-P.: Le calendrier employé par Eusèbe de Césarée dans les Martyrs de Palestine. Anal. Boll. 96, 1978, 55-64. His hypothesis is rejected by BARNES, T. D.: Constantine and Eusebius. Cambridge MA-London 1981, ch. 9. Persecution n. 21.

${ }^{12}$ On the topic also see STROBEL, A.: Ursprung und Geschichte des frühchristlichen Osterkalenders. TU 121. Berlin 1977; STROBEL, A.: Texte zur Geschichte des frühchristlichen Osterkalenders. Liturgiewissenschaftliche Quellen und Forschungen 64. Münster 1984; CANTALAMESSA, R.: Ostern in der Alten Kirche. Traditio Christiana 4. Bern 1981; ZERnOv, N.: Eusebius and the Paschal Controversy at the End of the Second Century. Church Quarterly Review 116, 1933, 14-41; PETERSEN, W. L.: Eusebius and the Paschal Controversy. Eusebius, Christianity, and Judaism. Ed. by H. W. Attridge and G. Hata. Detroit 1992, 311-325.

${ }^{13}$ On Maximin: Eusebius MP rec. brev. 3, 5. On the new governors: 3, 1 (Urban); 7, 7 (his putting down); 8, 1 (his successor, Firmilian). 


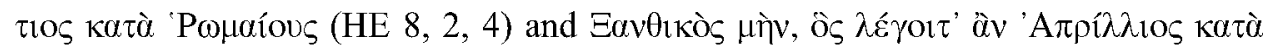
'Pouxíous (MP prooem. 1). A possible explanation can be that at the beginning of

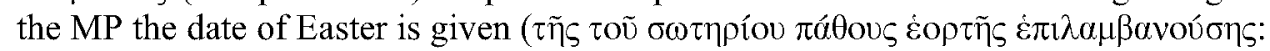
MP prooem. 1), while in the HE the feast was only approaching ( $\tau \tilde{\eta} \varsigma \tau$ ธo $\sigma \omega \tau \eta \rho i ́ o v$

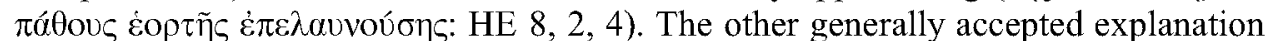
is that the date given in the introductory part of the MP rec. brev. is the date when Diocletian's first decree was published in Caesarea in Palestine.

(3) Two of the four dates cited can also be explained by an attempt to synchronize: the first one is the day of the execution of the first Palestinian martyr, Procopius, the second one is Maximin's birthday, as connected to Agapius' execution. The date of Adrian's execution is similarly given according to the Macedonian and Roman calendars on the one hand, and with reference to the feast of Tyche, the pagan goddess of the city, probably one of the biggest events in Caesarea, on the other: $\Delta$

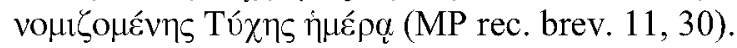

(4) The 'corruption' of the text can be explained by the fact that after the Council of Nicea (325) a uniform method was used for setting the date of Easter everywhere and the calendar became fixed. Thus when the copies of the MP and the Syriac translation were completed the Parasceue did not fall on the days given according to the Macedonian and Roman calendar - if any scriptor ever took the trouble to check the date at all. It is even less probable that the dates should have been inserted later, because in this case we would have to account for the absence of insertions in the other cases.

(5) There is another place where Eusebius refers to Friday with the phrase $\dot{\eta}$

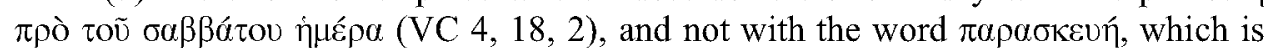
fairly common in Eusebius' oeuvre with the meaning 'preparation'. In his De solemnitate Paschali the two expressions are clearly different in meaning.

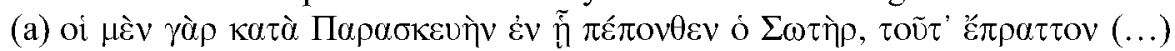
(pasch. $9=$ PG 24, 704B). The word Парабкєuń means Good Friday here.

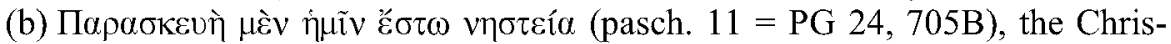
tians have to fast on Good Friday.

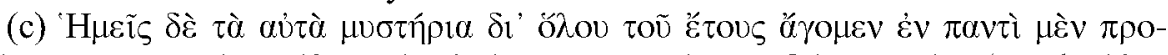

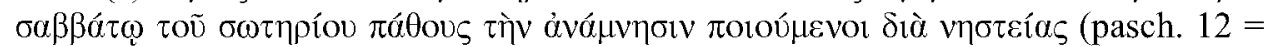
PG 24, 705C), remembering the sufferings of the Saviour, Christians fast not only on

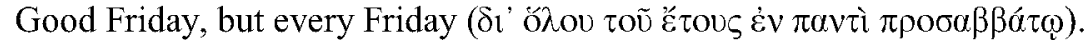

(6) In my opinion the fourth date must refer not to a common Sunday, but to

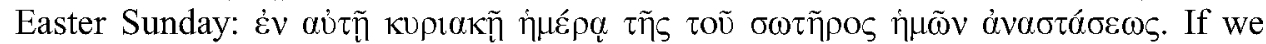

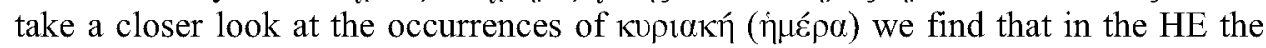
expression is used both for Sunday (HE 4, 26, 2: in a title; 3, 27, 5: in plur.; 4, 23, 11: the meaning is uncertain and could be either) and for Easter Sunday (HE 5, 23, 1-2; $5,24,11$ ), but in the Vita Constantini, which was written after Constantine's decree on the celebrating of Sunday (321) ${ }^{14}$ and the Council of Nicea (325) Eusebius uses

${ }^{14}$ Eusebius VC 4, 18, 2. Cf. CTh 2, 8, 1 and CI 3, 12, 2 . 
the word only in the meaning of Sunday (VC 4, 18, 1: twice; 4, 19: in plur.; 4, 23; cf. pasch. $12=$ PG 24, $705 \mathrm{C}$ )

(7) Every event taking place during the days of Easter was of great importance, and Eusebius writes about or quotes a report of several of these (HE 6, 9, 2-3; 6, 34); the most important ones being obviously the executions of martyrs (HE 2, 23, 10-18; $7,22,4)$.

University of Szeged

H-6722 Szeged, Egyetem u. 2. 